\section{Avaliação da influência da infecção bacteriana secundária na evolução da leishmaniose cutânea causada por Leishmania (Viannia) braziliensis em Corte de Pedra, Bahia, Brasil}

Entre agosto de 1998 e janeiro de 1999 foi feita uma avaliação em 84 pacientes com leishmaniose tegumentar americana, em Corte de Pedra (Bahia, Brasil), com o objetivo de verificar-se a prevalência de infecção bacteriana secundária das úlceras leishmanióticas cutâneas, identificar as bactérias responsáveis, e estudar sua relação com o processo de reepitelização destas lesões. A infecção bacteriana secundária foi definida como o isolamento de bactérias patogênicas em culturas de amostras de tecido obtidas mediante biópsia da borda da lesão leishmaniótica mais antiga de cada paciente. Foram pesquisadas bactérias aeróbias e micobactérias, mediante semeadura em meios de ágar-sangue, ágar Mac Conkey e LöwensteinJensen, respectivamente. Investigou-se também a presença do Corynebacterium diphtheriae em amostras obtidas mediante swab da parte interna da borda da lesão ulcerada e semeadas em meio de Pai. Todos os pacientes receberam tratamento endovenoso com antimoniato de meglumina e fizeram lavagem da úlcera com água e sabão comum. Os pacientes com evidência clínica de infecção bacteriana secundária, observada além dos limites da úlcera, foram tratados com cotrimoxazol pela via oral. A casuística foi composta principalmente de adolescentes e adultos, com predomínio do sexo masculino, dedicados à lavoura. A maioria dos pacientes (69\%) apresentou lesão única, e quase a metade (48\%) das lesões ulceradas mais antigas estiveram localizadas nas pernas e nos pés. As lesões ulceradas localizadas abaixo dos joelhos foram de maior tamanho quando comparadas com as localizadas acima. Verificou-se a presença de infecção bacteriana secundária em 54,3\%, com predomínio do Staphylococcus aureus (89\%). O Corynebacterium

\section{Evaluation of the secondary bacterial infection's influence on the evolution of cutaneous leishmaniasis caused by Leishmania (Viannia) braziliensis in Corte de Pedra, Bahia, Brazil}

Between August 1998 and January 1999, 84 patients with American cutaneous leishmaniasis were evaluated in the municipality of Corte de Pedra, a known endemic area from Bahia (Brazil), in order to study the presence of secondary bacterial infection in the ulcerated leishmanial lesions and its relationship to the healing process. Diagnosis of secondary bacterial infection of the leishmanial lesions was made when a bacterial pathogen was isolated from the border's tissue specimen of the oldest ulcer from each patient. Cultures were done in blood and Mac Conkey agars as well as in Löwenstein-Jensen medium for the isolation of aerobic bacteria and mycobacteria, respectively. Final bacterial identification was effected with usual procedures. Swabs from the inner part of the ulcer's border inoculated in the selective Pai medium was used for Corynebacterium diphtheriae isolation. All the patients received intravenous antimonial therapy and the ulcer was washed with common soap and water. Those with clinical evidence of extralesional (surrounding) bacterial infection also received oral treatment with cotrimoxazole. Of the patients, adolescent and adult male farm workers predominated. Single lesions were observed in $69 \%$. Almost half (48\%) of the ulcerated lesions were encountered on legs and feet. Size of the ulcer was greater in lesions situated below the knee. Secondary bacterial infection was found in $54.3 \%$. Staphylococcus aureus was the most frequent bacteria isolated (89\%). Corynebacterium diphtheriae was encountered in $8.3 \%$. No mycobacteria species were isolated. Secondary bacterial infection was more frequent in lesions located below rather than above the knee. Final evaluation was made in 79 of the 84 patients initially included at onset of the study, because 
diphtheriae foi isolado em $8,3 \%$. Não foi isolada nenhuma espécie de Mycobacterium. As lesões localizadas abaixo dos joelhos tiveram uma maior freqüência de infecção bacteriana secundária, quando comparadas com as localizadas acima. A avaliação final foi feita em 79 pacientes, devido a que dos 84 incluídos inicialmente, três receberam co-trimoxazol e dois foram retirados do estudo por diversas razões. O processo de reepitelização completa esteve influenciado negativamente, e de forma independente, pela localização das lesões abaixo dos joelhos e pelo maior tamanho da úlcera. Não houve associação entre a presença de infecção bacteriana secundária e o processo de reepitelização completa nas lesões leishmanióticas ulceradas, um mês após o término do tratamento. three received cotrimoxazole and two were withdrawn for other reasons. Healing impairment of the ulcers was observed more frequently in lesions situated below the knee and, independently of location, among those with greater size. There was no association between secondary bacterial infection and the healing process of the leishmanial ulcers evaluated one month after finishing antimonial treatment.

\section{Luis Angel Vera Luján}

Tese apresentada ao Núcleo de Medicina Tropical e Nutrição da Universidade de Brasília para obtenção do Título de Mestre.

Brasília, DF, Brasil, 1999. 